\title{
Research Article \\ Sizing and Simulation of PV-Wind Hybrid Power System
}

\author{
Mustafa Engin \\ Ege Higher Vocational School, Department of Electronics Technology, Ege University, 35100 Izmir, Turkey
}

Correspondence should be addressed to Mustafa Engin; mustafa.engin8@gmail.com

Received 9 October 2012; Revised 29 December 2012; Accepted 10 February 2013

Academic Editor: Mohammad A. Behnajady

Copyright (C) 2013 Mustafa Engin. This is an open access article distributed under the Creative Commons Attribution License, which permits unrestricted use, distribution, and reproduction in any medium, provided the original work is properly cited.

\begin{abstract}
A sizing procedure is developed for hybrid system with the aid of mathematical models for photovoltaic cell, wind turbine, and battery that are readily present in the literature. This sizing procedure can simulate the annual performance of different kinds of photovoltaic-wind hybrid power system structures for an identified set of renewable resources, which fulfills technical limitations with the lowest energy cost. The output of the program will display the performance of the system during the year, the total cost of the system, and the best size for the PV-generator, wind generator, and battery capacity. Security lightning application is selected, whereas system performance data and environmental operating conditions are measured and stored. This hybrid system, which includes a PV, wind turbine, inverter, and a battery, was installed to supply energy to $24 \mathrm{~W}$ lamps, considering that the renewable energy resources of this site where the system was installed were $1700 \mathrm{Wh} / \mathrm{m}^{2} /$ day solar radiation and $3.43 \mathrm{~m} / \mathrm{s}$ yearly average wind speed. Using the measured variables, the inverter and charge regulator efficiencies were calculated as $90 \%$ and $98 \%$, respectively, and the overall system's electrical efficiency is calculated as $72 \%$. Life cycle costs per kWh are found to be $\$ 0.89$ and LLP $=0.0428$.
\end{abstract}

\section{Introduction}

Renewable energy resources like solar and wind offer clean and economically competitive alternatives to conventional power generation where high wind speed and high solar radiation are available. For meeting the energy demand, PVwind hybrid power generating systems can be beneficial in enhancing the economic and environmental sustainability of renewable energy systems. Growing public concerns over global warming as an impending outcome of greenhouse gas emissions initiated by energy resources based on fossil fuels have encouraged to study cleaner energy options, like PV, biomass, wind, and micro hydro systems for several applications. The record of worldwide photovoltaic (PV) market installations extended up to $27.4 \mathrm{GW}$ in 2011 [1]. On the other hand, the commercial wind turbine installations around the world have expanded to $240 \mathrm{GW}$ by the end of 2011 [2].

Renewable resources such as solar and wind energy which change randomly are individually less reliable. However, in many regions, when solar and wind resources are combined for power generation, they complement each other by means of daily and seasonal variations. Combining these two renewable energy sources could make the system more reliable, and the system costs might slightly decrease depending on the regional conditions. However, the energy system sizing procedure and operation control strategies are getting more complex due to the nonlinear components' physical characteristics.

Photovoltaic-wind hybrid power systems are categorized as extraordinary complex in sizing and optimization process, where renewable energy resources and storage components must be sized to match the given load profile and the estimated ease of use of solar radiation and wind speed. Many $\mathrm{PV}$-wind hybrid systems are unique in design, whereas the complete dynamic testing of hybrid system takes very long time and also its cost is very high. In some way, whether necessary time and budget are provided for the dynamic tests, it is very hard to test all the situations that will be met during the life cycle of the hybrid system. It is clear that if the individual performance does not match with the expected simulation outcomes, it leads the user to uncertainty. Without exact high-level comparisons between real objective performance and projected computer simulations, it is very hard to focus on enlightening the performance of PV-wind hybrid system. A reliable technique for assessing the performance of a hybrid power system at a specific location is an essential prerequisite 
for boosting investment in hybrid power systems. Such a technique is also suitable for comparing the performance of two hybrid power systems, specific conditions at a certain location [3]. For this reason, software design and simulation tools are important aids.

Several economic viability and technical availability studies are carried out to assess choice of PV-wind hybrid power systems configurations that serve power to the load with the certain reliability criteria [4-11]. The number of PV panels, wind turbines, battery cells, load profiles and available renewable resources plays a significant role in sizing of PV-wind hybrid power system. Researchers and scientists mostly use deterministic and probabilistic methods to size and simulate the PV-wind hybrid power system. In deterministic method, time-series data such as wind speed, solar radiation, ambient temperature, load profile, and site geographic position like latitude, longitude, and altitude are assumed to be known. Resource data like wind speed, solar radiation, ambient temperature, and load profile are needed, at least hourly basis for whole year [12-15]. Also on the chronological order of the resource data is really important. Frequency of time-series resource data is defined according to the chosen simulation step time period. In probabilistic method, resource data and load profile are assumed as random variables, and these variables may not be in the chronological order. Probabilistic method tries to develop appropriate stochastic model for power generation and power consumption and then combines these two models to determine a hybrid system risk model. A group of researchers reported two sizing methods for autonomous PV-wind hybrid power systems. The first one assesses hybrid system performance using energy to load ratio which is based on the yearly average of monthly hybrid system energy outputs [16-19]. The second one realizes battery to load ratio using the worst monthly scenario [2022]. The other probabilistic method is proposed by Yang et al. [23]. The authors proposed to use a typical meteorological year (TMY) to find out a precise assessment of energy output of a PV-wind hybrid power system. Tina and Gagliano [24] sized a PV-wind hybrid power system with probabilistic method that is based on convolution technique by probability density function. Deterministic and probabilistic sizing and simulation methods have their own advantages and disadvantages. Sizing procedure utilizing deterministic approach has severe computational efforts and it gives suboptimum solutions depending on the type of the used resource data, whereas stochastic procedures are simple and also they may use daily or monthly average resource data instead of timeseries resource data.

In this paper, a hybrid system model that covers costing and system performance variables is identified. Decision variables, objective function, and constraints are determined for this model. Using simple iterative technique, sizing variable and performance variables are optimized according to the objective function under constraints.

\section{Material and Method}

2.1. Solar Evaluation Instruments and Measurements. The solar-wind meteorological station is located on the roof of
TABLE 1: Main characteristics of the Solar-Wind Meteorological Station at the Solar Energy Institute.

\begin{tabular}{lcc}
\hline Module & Parts & Specification/description \\
\hline \multirow{4}{*}{ Sensor } & Wind speed & Accuracy $0.5 \mathrm{~m} / \mathrm{s}$ \\
& Wind direction & Precision $0.8 \mathrm{~m} / \mathrm{s}$ \\
& Pyronometer & $4.7 \mu \mathrm{V} / \mathrm{W}$ \\
& Ambient temperature & -40 to $56^{\circ} \mathrm{C}$, accuracy $<0.5^{\circ} \mathrm{C}$ \\
& Relative humidity & $12-100 \%$, accuracy $<3 \%$ \\
\hline \multirow{4}{*}{ Data logger } & Signal input & 12 channels \\
& Memory & 2 Mbytes \\
Power & Computer connector & RS-232 \\
Tripod & PV module & $15.1 \mathrm{~V}, 10 \mathrm{~W}_{\text {Peak }}$ \\
\hline
\end{tabular}

the Solar Energy Institute Building in Ege University for determining the local potentials of both solar and wind energy [25]. This station consists of four modules, namely, sensors, data logger, electric power, and a tripod kit. Table 1 gives the specification of the equipment used for the solar radiation, wind speed and direction, ambient temperature, and relative humidity measurements. The station is fully operated with solar energy using $10 \mathrm{~W}$ PV module [26] with $12 \mathrm{~V} 12$ Ah battery backup [27] and hereby the additional energy is not needed. The data gathering is made at an interval of ten minutes and the monthly average values are also logged. The meteorological station was installed in January 2005 and the measurements have been carried out since then.

2.2. PV-Wind Hybrid System. PV-wind hybrid energy system's main components are shown in Figure 1. PV array and wind turbine generate energy for the load. Battery stores excess energy and supplies the load when the generated energy is not enough for the load. Battery charge controllers keep battery voltage within specific voltage window and thus, they prevent overdischarge or overcharge regimes. To protect the battery against overcharging, PV array and wind generator is disconnected from the system when the DC bus voltage increases above $V_{\text {max-off }}$ and when the current required by the load is less than the current generated by the PV array and wind generator. They are connected again when DC bus voltage decreases below $V_{\max \text {-on }}$. To protect the battery against excessive discharging, the load is disconnected when the DC bus voltage falls below $V_{\text {min-off }}$ and when the current required by the load is greater than the current generated by the PV array and wind generator. The load is switched on when DC bus voltage increases above $V_{\text {min-on }}$. The inverter converts generated energy from DC to AC for an AC load.

2.3. PV Module Performance Model. A PV module consists of a number of solar cells connected in series and parallel to obtain the desired voltage and current output levels. Each solar cell is basically a p-n diode. As sunlight strikes a solar cell, the incident energy is converted directly into electrical energy. Single-diode mathematic model is applicable to simulate silicon photovoltaic cells, which consists of a photocurrent source $I_{\mathrm{ph}}$, a nonlinear diode, and internal resistances 


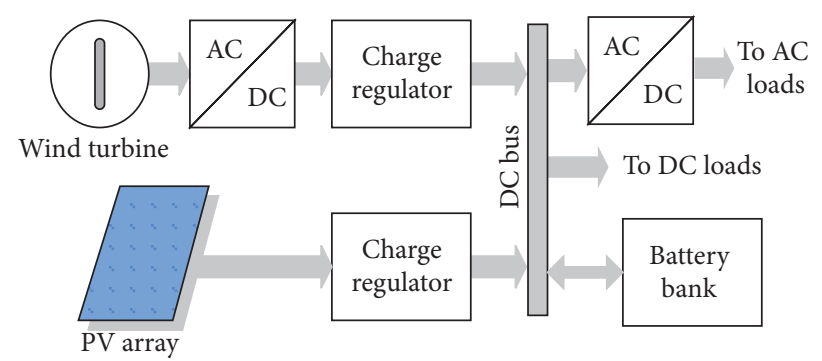

FIGURE 1: Hybrid energy system components.

$R_{S}$ and $R_{p}$, as shown in Figure 2. In the manufacturer's datasheets, usually basic electrical characteristics of a PV module are given. We may obtain short-circuit current, opencircuit voltage, and the maximum power point (MPP) current and voltage values that are available in the datasheet. In addition, the manufacturer's datasheet provides PV cell temperature coefficients referred to as current and voltage. Module current and voltage values depend on temperature and irradiance. The temperature coefficient of the cell referred to as voltage is negative and large. On the other hand, the temperature coefficient of current is positive and small. In some PV cell models, current variations with temperature can be neglected, and the voltage variations with temperature are defined for a PV module consisting of $N_{c}$ cells connected in series [28].

The operating temperature of the cell, which differs from the ambient temperature, determines the open-circuit voltage. The operating temperature of a cell can be calculated using (1) for a given ambient temperature [29] as

$$
T_{C}=T_{a}+0.03 \cdot G_{a},
$$

where $T_{C}$ is the operating cell temperature, $T_{a}$ is the ambient temperature in Kelvin, and $G_{a}$ is the irradiance in $\mathrm{W} / \mathrm{m}^{2}$. Open-circuit voltage of the cell can be calculated using

$$
V_{\mathrm{OC}}^{C}=V_{\mathrm{OC}, 0}^{\mathrm{C}}+(-2.3 \mathrm{mV} / \mathrm{C})\left(T_{\mathrm{C}}-T_{0}^{C}\right) \text {. }
$$

For the PV cell, the short-circuit current is proportional to the irradiance where the open-circuit voltage is a logarithmic function of the current. Using (3), short-circuit current of a PV cell can be calculated for a given irradiance [30]:

$$
I_{\mathrm{SC}}^{C}=\frac{I_{\mathrm{SC}, 0}^{\mathrm{C}} G_{a}}{G_{a, 0}} .
$$

PV module's short-circuit current is proportional to the number of parallel connected PV modules:

$$
I_{\mathrm{SC}}^{M}=N_{\mathrm{PC}} \cdot I_{\mathrm{SC}}^{\mathrm{C}} \text {. }
$$

PV module's open-circuit voltage can be calculated using

$$
V_{\mathrm{OC}}^{M}=N_{\mathrm{SC}} \cdot V_{\mathrm{OC}}^{\mathrm{C}} \text {. }
$$

The equivalent series resistance of the module can be calculated as

$$
R_{S}^{M}=\frac{N_{\mathrm{SC}}}{N_{\mathrm{PC}}} \cdot R_{S}^{C}
$$

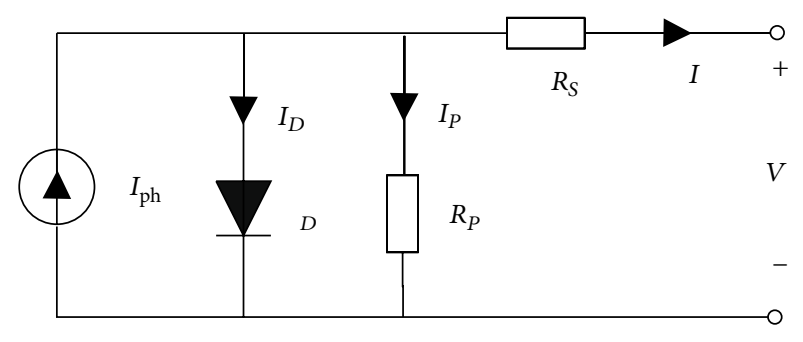

FIGURE 2: Single-diode mathematical model of a PV cell.

The PV module's current $I^{M}$ under arbitrary operating condition can be described as

$$
I^{M}=I_{\mathrm{SC}}^{M}\left[1-\exp \left(\frac{V^{M}-V_{\mathrm{OC}}^{M}+R_{\mathrm{S}}^{M} \cdot I^{M}}{N_{\mathrm{SM}} V_{t}^{C}}\right)\right] .
$$

The necessary number of PV modules to be connected in series is derived by the number of modules needed to match the bus operating voltage as depicted in

$$
V_{\mathrm{PV}}=V_{\mathrm{OC}}^{M} \cdot N_{\mathrm{SM}} \cdot
$$

The current output of a PV array at time $t, I^{M}(t)$, is related to the number of parallel strings as [30]

$$
I_{\mathrm{PV}}(t)=I^{M}(t) \cdot N_{\mathrm{PM}} \cdot f_{\mathrm{MM}} \cdot
$$

The power output of the PV array at time $t$ is

$$
P_{\mathrm{PV}}(t)=I_{\mathrm{PV}}(t) \cdot V_{\mathrm{PV}}(t) .
$$

2.4. Wind Turbine Performance Model. Characteristic curves for wind turbines are given as power output versus wind speed at the hub height. Wind turbines are never connected in series [31]. Several wind turbines can be connected in parallel to match the system current requirements. This can be done with parallel strings of the same wind turbine type or with strings of a different wind turbine type. It is assumed here that at most two different turbine types are used at the same time in one system. Yearly energy densities for wind are calculated using

$$
P_{\mathrm{WT}}=0.5 \cdot C_{p} \cdot \rho_{\mathrm{air}} \cdot v^{3} .
$$

If we assume the average yearly energy demand as $D$, we can determine average wind turbine diameter $D_{\mathrm{WT}}$ using (12), so that wind turbine type can be defined easily [32]:

$$
D_{\mathrm{WT}}=\sqrt{\frac{D_{\mathrm{av}, \text { year }}}{\text { hours } / \text { year } \cdot P_{W} \cdot \pi \cdot(1 / 4)}} .
$$

The power output of the wind turbine array at time $t$ is

$$
P_{\mathrm{WT}}(t)=0.5 C_{p} \rho_{\text {Air }} v^{3}(t) .
$$




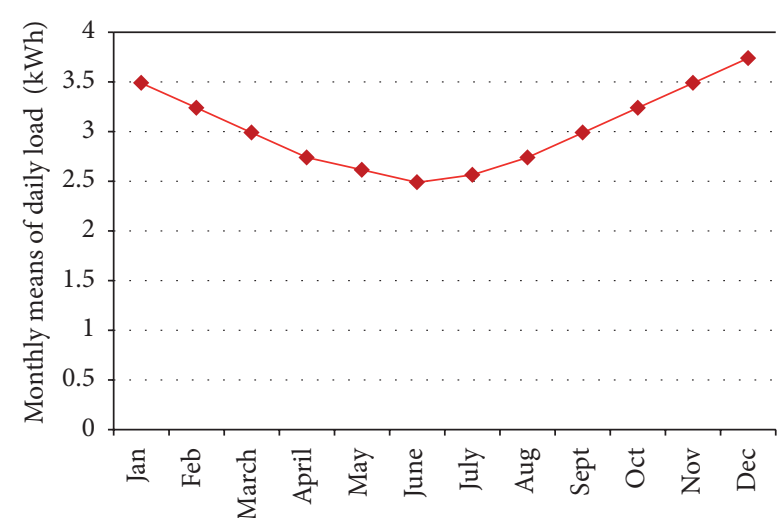

Figure 3: Monthly means of daily load profile of PV-wind hybrid system.

2.5. Battery Performance Model. Batteries in a hybrid system are connected in series to obtain the appropriate nominal bus voltage. Therefore, the number of batteries connected in series for the same type of battery in a battery bank is calculated as follows

$$
N_{\mathrm{SBat}}=\frac{V_{\mathrm{PV}}}{V_{\mathrm{Bat}}} .
$$

The hybrid system can have several different types of battery banks. The battery state of charge of a battery bank at time $t$ is calculated based on adding the charge current (positive sign) or discharge current (negative sign) to the battery bank state of charge at the previous time instant. When adding the battery current to the battery state of charge, self-discharge losses and battery charging losses should be taken into account [33]:

$$
\begin{aligned}
& \operatorname{SOC}(t+1) \\
& =\sum_{i=0}^{\text {BatBan }}\left[\operatorname{SOC}_{i}(t) \cdot \sigma_{i}+I_{\mathrm{Bat}}(t) \cdot \Delta t \cdot \eta_{i\left(I_{\mathrm{kolbat}}(t)\right)}\right] \cdot N_{\mathrm{PBat}} \cdot
\end{aligned}
$$

2.6. Inverter, Charger, and Loads Performance Model. The inverter characteristics can be described by the inverter input-output relationship. Some of the power supplied to the inverter will be lost due to transformation losses that are named inverter efficiency losses, $\eta_{\text {inv }}$ :

$$
P_{\text {inv-ip }} \cdot \eta_{\text {inv }}=P_{\text {inv-op }}, \quad \eta_{\text {inv }}=f\left(P_{\text {inv-op }}\right) .
$$

In fact, charge regulators can be modeled as a switch, which connects and disconnects generator to battery or load according to battery state of charge, temperature, or load demand [34]. The output power, $P_{\mathrm{BC} \text {-op }}$, of the battery charger is equal to the input power, $P_{\mathrm{BC} \text {-ip }}$, multiplied by the efficiency losses during the energy conversion. Efficiency losses depend nonlinearly on the DC output power and therefore nonlinearly on the DC output current of the battery charger:

$$
P_{\text {iBC-ip }} \cdot \eta_{\mathrm{BC}}=P_{\text {BC-op }}, \quad \eta_{\mathrm{BC}}=f\left(P_{\text {BC-op }}\right) \text {. }
$$

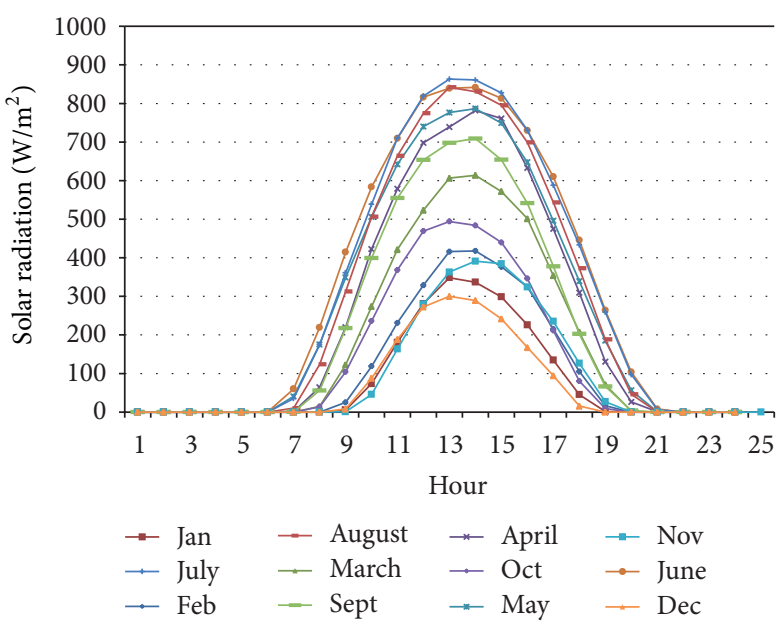

FIGURE 4: Hourly average of solar radiation data for 12 months of the year.

Efficiency losses can be calculated from efficiency losses versus output power curves that are given by the manufacturers. In most cases, two types of loads are present, DC appliances of $12 \mathrm{~V}, 24 \mathrm{~V}$, and $48 \mathrm{~V}$ or AC appliances of $220 \mathrm{~V}$. The estimated power consumption should be given in intervals of hours, days, or years. If both a DC and an AC generator exist, some of the DC generators energy can be routed through the inverter to the AC loads:

$$
I_{\mathrm{Gdc}} \geq I_{\mathrm{dcL}}, \quad \text { or } \quad I_{\mathrm{Gdc}}=I_{\mathrm{dcL}}+I_{\text {inv-ip }} .
$$

2.7. Costing Model of Hybrid System. It is stated by SeelingHochmuth in 1998 that in life cycle costing equipment and operation costs are compiled and discounted over the assumed project life. The hybrid system life cycle costs (LCCs) are defined as the initial investment and future discounted operation costs:

$$
\mathrm{LCC}=\left[C_{C}+\sum_{i=1}^{\text {Number of Components }} \text { Discounted } C_{\mathrm{OP}, i}\right] .
$$

The hybrid system operation costs are in general nonlinear and depend largely on the component size and type, and the way the system is operated. As they depend on future operations, they can only be estimated roughly [35].

The sizing variables are sizes of component types and their number is to be installed. From the PV module, wind turbine, battery, battery charger, and inverter performance models sizing variables are defined as follows:

$$
\begin{aligned}
& N_{\text {SBat }}, N_{\text {PBat }}, N_{\mathrm{SM}}, N_{\text {PM }}, N_{\text {PWT }}, N_{\text {Pin }}, \\
& \mathrm{PV}_{\text {type }}, \mathrm{WT}_{\text {type }}, \mathrm{IN}_{\text {type }}, \mathrm{BC}_{\text {type }}, \mathrm{BAT}_{\text {type }}
\end{aligned}
$$

Hybrid system must include operation strategies that describe the energy flow between the generator and the load. The operation decision variables to be optimized represent routing and operation decisions that are based on the power 

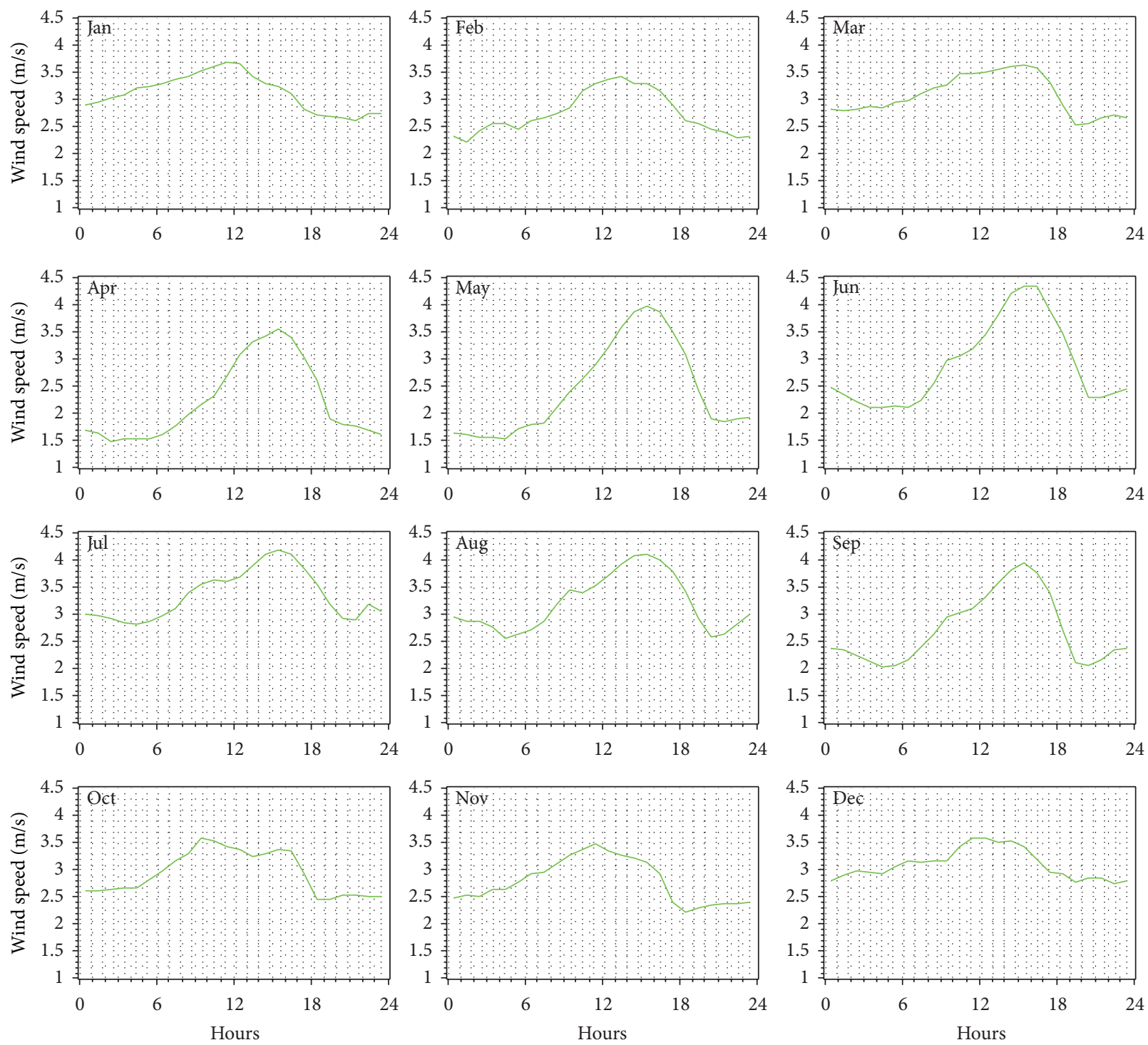

FIGURE 5: Hourly average of wind speed data for the 12 months of the year.

flow modeled for the hybrid system. The main operation decision variables of the hybrid system model are minimum battery stage of charge, $\mathrm{SOC}_{\min }$, maximum battery stage of charge $\mathrm{SOC}_{\max }$, PV battery charger control switch, $\mathrm{CS}_{\mathrm{CPV}}$, wind turbine battery charger control switch $\mathrm{CS}_{\mathrm{CWT}}$, inverter control switch $\mathrm{CS}_{\mathrm{IN}}$, and load control switch $\mathrm{CS}_{\mathrm{L}}$. Some of these decision variables may be set before optimization of hybrid system. The hybrid system model has many constraints concerning technological, socioeconomic, legal, or physical aspects. The constraints in the presented approach are given by technical characteristics of battery operation and by matching demand and generated energy. Constraints can be formulated as follows:

$$
\begin{gathered}
\operatorname{SOC}(t) \geq \operatorname{SOC}_{\text {min }}, \\
\operatorname{SOC}_{\text {min }}=1-\mathrm{DOD}_{\text {max }},
\end{gathered}
$$

where $\mathrm{DOD}_{\max }$ is the maximum depth of discharge of the battery. Consider

$$
I_{\mathrm{PV}}(t)+I_{W}(t)+I_{\mathrm{BD}}(t) \geq I_{\text {load }}(t)+I_{\mathrm{BC}}(t) .
$$

Equation (22) cannot always be proved. According to various applications, load may not be served with desired amount of energy. This situation is described as loss of load probability (LLP). LLP of the energy system can be calculated using (23). Also, LLP is the size of system reliability:

$$
\text { LLP }=\frac{\text { Energy_Demand }}{\text { Energy_Served }} \text {. }
$$

The objective of optimization procedure is to achieve hybrid system that generates energy with the lowest cost. The hybrid 


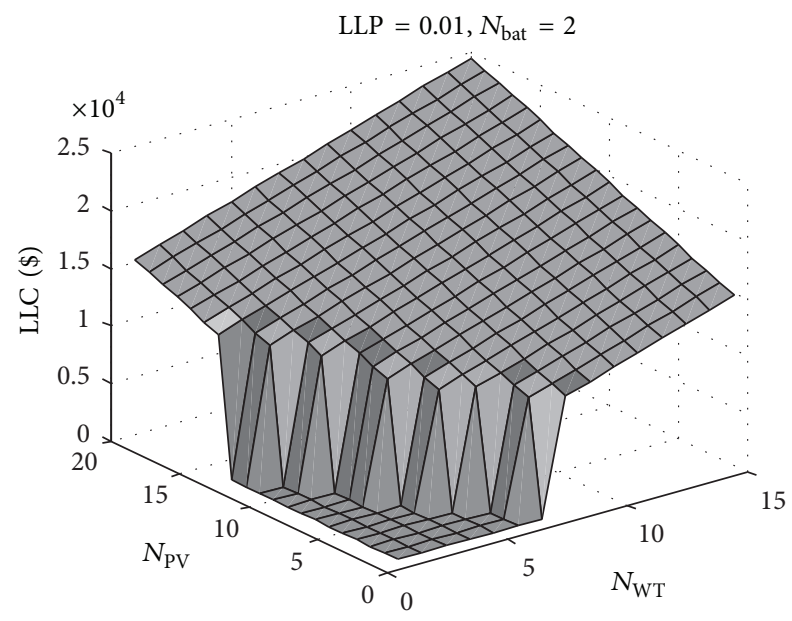

FIGURE 6: LCC versus $N_{\mathrm{WT}}, N_{\mathrm{PV}}$ for LLP $=0.01$ and $N_{(\text {bat, string })}=2$.

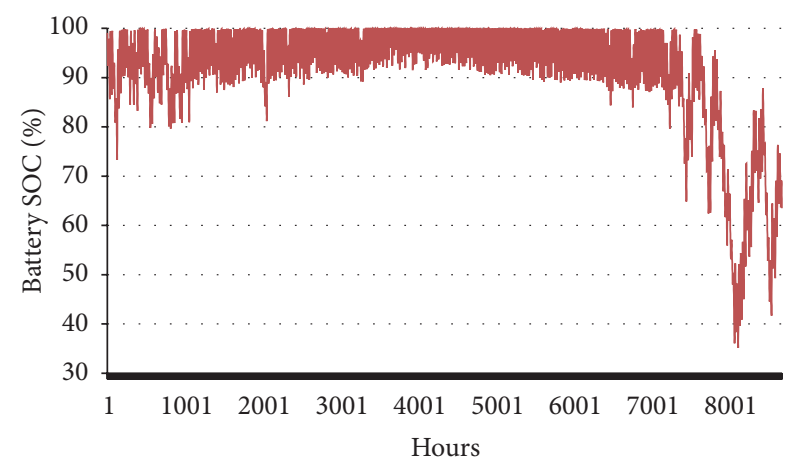

FIgURE 7: Simulation result of battery SOC.

system model needs to be optimized with respect to the decision variables and operation strategies such that a minimum of the life cycle costs is achieved [36].

\section{Results and Discussion}

3.1. Case Study. This section demonstrates the effectiveness of the proposed methodology by means of an implication of PV-wind hybrid system. The developed methodology is used to project a PV-wind hybrid power system for security lighting in the Solar Energy Institute Building. Inputs of the project are load profile, and hourly average of solar radiation, ambient temperature, and wind speed resource data for whole of the year. The load on the system is an experimental lighting of Solar Energy Institute. Load demand changes according to the period of the night. For the purposes of validating the model performance, the proposed algorithm is coded and simulated with MATLAB V 7.7 [37] that will also be employed as a software tool during optimization. The monthly means of daily average loads are shown in Figure 3. Daily resource data were calculated using monthly mean solar radiation and wind speed, and the results are shown in Figures 4 and 5, respectively.
TABLE 2: Hybrid system component's initial values of sizing variables, and type of system components.

\begin{tabular}{lcc}
\hline Variables & Symbol & Initial value or type \\
\hline $\begin{array}{l}\text { Number of series connected } \\
\text { modules }\end{array}$ & $N_{\mathrm{SM}}$ & 2 \\
DC bus voltage & $V_{\mathrm{DC}}$ & 24 volts \\
Battery cell voltage & $V_{\mathrm{Bat}-\mathrm{Cell}}$ & 2 volts \\
Number of series connected & $N_{\mathrm{SBatt}}$ & 12 \\
batteries & $\mathrm{PV}_{\text {type }}$ & $\mathrm{SM} 50$ \\
PV module type & $\mathrm{WT}_{\text {type }}$ & 3 blades, PMSG \\
Wind turbine type & $\mathrm{IN}_{\text {type }}$ & True sine wave \\
Inverter type & $\mathrm{Q}_{\text {cell }}$ & $110 \mathrm{Ah}$ \\
Battery cell capacity & $P_{\mathrm{WT}}$ & $400 \mathrm{~W}$ at $10 \mathrm{~m} / \mathrm{s}$ \\
Wind turbine power & $P_{\mathrm{PVM}}$ & $50 \mathrm{~W}$ peak \\
PV module power & &
\end{tabular}

TABLE 3: The optimized hybrid system configuration.

\begin{tabular}{lcccc}
\hline PV system & $\begin{array}{c}\text { Wind } \\
\text { turbine }\end{array}$ & Inverter & Battery capacity & Load \\
\hline $500 \mathrm{~W}$ & $400 \mathrm{~W}$ & $300 \mathrm{~W}$ & $2.64 \mathrm{kWh}$ & $24 \times 12=288 \mathrm{~W}$ \\
\hline
\end{tabular}

Using MATLAB code, the initial values of sizing variables referred to as hybrid system components and type of system components were defined and shown in Table 2. Equation (15) was optimized with respect to $N_{\mathrm{Bat}}, N_{\mathrm{PV}}, N_{\mathrm{WT}}$, $\mathrm{BC}_{\text {type }}$, and operation strategies to minimize the life cycle costs. Using simple iteration technique, sizing variables were defined and the results are shown in Figure 6. Because of the economical constraint and availability of wind turbine, $N_{\text {WT }}$ is set to 1 instead of 2 , and then the system was reoptimized according to one wind turbine. And then the LLP value was revised to be 0.0738 . Using defined sizing variables and operation strategies, the hybrid system model was simulated according to hourly weather data, and SOC is shown in Figure 7. Life cycle costs per kWh are calculated as $\$ 1.0076$. The optimized hybrid system configuration is shown in Table 3.

Configured PV-wind hybrid power system with battery backup was installed with the monitoring system in January 2009; wind turbine and PV array are shown in Figure 8. The monitoring system and battery bank, inverter, and DCDC converters for PV and wind turbine were placed in the laboratory for ease of uploading the logged values which are presented in Figure 9.

For the assessment, the system was monitored for oneyear period logged from January 2009 to January 2010. Battery voltage, load voltage, load current, battery current, PV output, and wind generator output currents have been measured with a sampling rate of $1 \mathrm{sec}$ and recorded as $10 \mathrm{sec}$ average values. Recorded data was uploaded to a computer, and thereafter daily, monthly, and yearly performance parameters have been calculated using these values of components and the hybrid system. 
TABLE 4: Results measured and calculated according to IEC 61724 for January 2009 to January 2010.

\begin{tabular}{|c|c|c|c|}
\hline Parameter & Symbol & Measured & Units \\
\hline \multicolumn{4}{|l|}{ Meteorological } \\
\hline Global direct irradiation & $H_{I}$ & 4.88 & $\mathrm{kWh} \mathrm{m}^{-2} \mathrm{~d}^{-1}$ \\
\hline $\begin{array}{l}\text { Global available wind } \\
\text { energy }\end{array}$ & $E_{\mathrm{GAW}}$ & 0.36 & $\mathrm{kWh} \mathrm{m}^{-2} \mathrm{~d}^{-1}$ \\
\hline \multicolumn{4}{|l|}{ Electrical energy quantities } \\
\hline $\begin{array}{l}\text { Net energy from the PV } \\
\text { array }\end{array}$ & $E_{\mathrm{PV}}$ & 811 & $\mathrm{kWh}$ \\
\hline Net energy from the WT & $E_{\mathrm{WT}}$ & 311 & $\mathrm{kWh}$ \\
\hline $\begin{array}{l}\text { Energy fraction from the } \\
\text { PV }\end{array}$ & $F_{\mathrm{PV}}$ & 0.71 & Dimensionless \\
\hline $\begin{array}{l}\text { Energy fraction from the } \\
\text { WT }\end{array}$ & $F_{\mathrm{WT}}$ & 0.29 & Dimensionless \\
\hline Total energy in the system & $E_{\text {in }}$ & 1142 & $\mathrm{kWh}$ \\
\hline Total energy used & $E_{\text {use }}$ & 822 & $\mathrm{kWh}$ \\
\hline Net energy to the load & $E_{L}$ & 822 & $\mathrm{kWh}$ \\
\hline \multicolumn{4}{|l|}{ BOS component performance } \\
\hline BOS efficiency & $\eta_{\mathrm{BOS}}$ & 72 & $\%$ \\
\hline \multicolumn{4}{|l|}{ System performance indices } \\
\hline PV array yield & $Y_{\mathrm{PV}}$ & 4.4 & $\mathrm{hd}^{-1}$ \\
\hline Final PV system yield & $Y_{\mathrm{fPV}}$ & 3.2 & $\mathrm{hd}^{-1}$ \\
\hline Wind turbine yield & $Y_{\mathrm{WT}}$ & 0.57 & $\mathrm{hd}^{-1}$ \\
\hline Final wind turbine yield & $Y_{\text {fWT }}$ & 0.41 & $\mathrm{hd}^{-1}$ \\
\hline \multicolumn{4}{|l|}{ Normalized losses } \\
\hline PV array capture losses & $L_{\mathrm{cPV}}$ & 34.2 & $\%$ \\
\hline PV BOS losses & $L_{\mathrm{BOSPV}}$ & 28 & $\%$ \\
\hline $\begin{array}{l}\text { Performance ratio for the } \\
\text { PV }\end{array}$ & $R_{\mathrm{pPV}}$ & 41.4 & $\%$ \\
\hline Wind turbine capture losses & $\mathrm{s} L_{\mathrm{cWT}}$ & 27.7 & $\%$ \\
\hline Wind BOS losses & $L_{\text {BOSWT }}$ & 37 & $\%$ \\
\hline $\begin{array}{l}\text { Performance ratio for the } \\
\text { WT }\end{array}$ & $R_{\mathrm{pWT}}$ & 46 & $\%$ \\
\hline \multicolumn{4}{|l|}{ System efficiencies } \\
\hline Average PV efficiency & $\eta_{\mathrm{PVmean}}$ & 9.3 & $\%$ \\
\hline Global PV efficiency & $\eta_{\text {PVtot }}$ & 6.72 & $\%$ \\
\hline Average WT efficiency & $\eta_{\mathrm{WTmean}}$ & 9.46 & $\%$ \\
\hline Global WT efficiency & $\eta_{\mathrm{WTtot}}$ & 6.86 & $\%$ \\
\hline
\end{tabular}

The data were analyzed following the International Electrotechnical Commission Standard (IEC) 61724 [38]. For $\mathrm{PV}$, the methodology of the standard was followed and for the wind part, a similar approach is applied, mainly following the procedure proposed by Arribas et al. [39]. The results are given in Table 4 . To test the effectiveness of the developed methodology, the studied PV-wind hybrid system performance parameters were also compared with simulation results.

Inverter and charge regulator efficiencies were calculated, 93\% and 98\%, respectively. The battery bank efficiency was derived from measured parameters and calculated as $82 \%$,

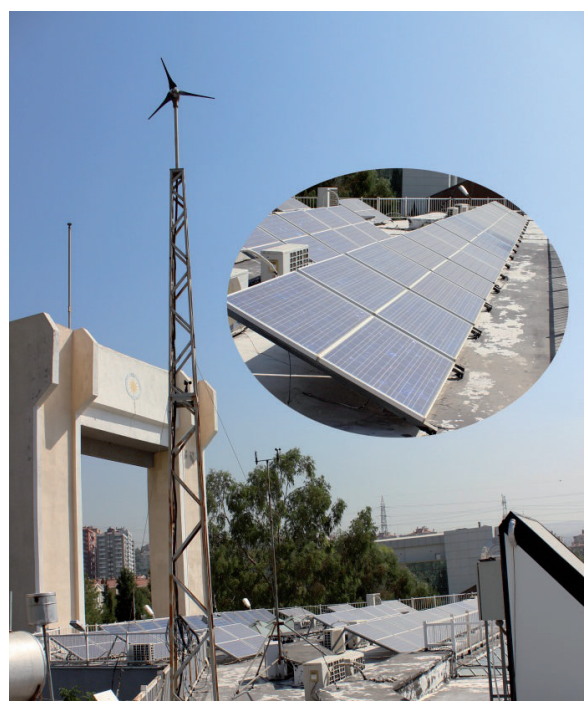

Figure 8: PV-wind hybrid system installed on the roof of Solar Energy Institute.

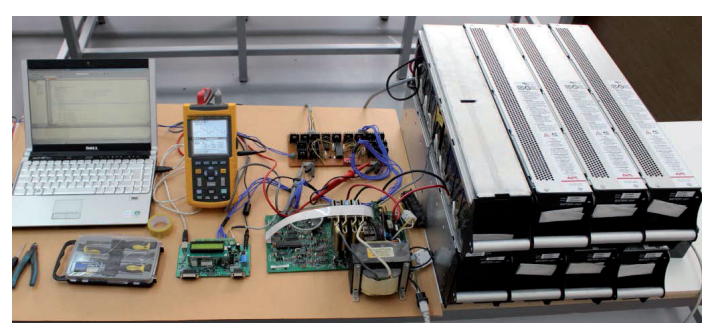

FIGURE 9: Datalogger, battery bank, DC-DC converters, and inverters in the laboratory.

which is 3 points less than the expected value. The overall system efficiency was calculated as $72 \%$. Life cycle costs per $\mathrm{kWh}$ was calculated as $\$ 0.89$ and LLP $=0.0428$. Using the measured variables, hourly changes of SOC were calculated and the result is presented in Figure 10.

$\mathrm{PV}$-wind hybrid power system directly converts solar and wind resources to electricity. This energy conversion process is void of gas emission. Consequently, one can say that it is entirely clean. But throughout the PV cell and wind turbine manufacturing processes and the transportation phase, they essentially consume a huge amount of energy; as a result, they emit considerable volume of greenhouse gases. PV systems emit $61 \mathrm{~g} \mathrm{CO}_{2}$-equiv./kWh [40-42] and wind turbine emits $21 \mathrm{~g} \mathrm{CO}_{2}$-equiv./kWh [43]. Accordingly, feeding load with the grid energy contributes to the greenhouse gasses emission. Table 5 compares the emissions caused by PV-wind hybrid system and grid-fed system. In Turkey, the energy from the grid is $76.1 \%$, produced with fossil fuel such as natural gas, coal, and oil which are sources of greenhouse gasses emission where the other part of energy is supplied by mainly hydropower, wind, and geothermal resources. The grid-tied systems in Turkey have greenhouse gasses emission of $493 \mathrm{~g} \mathrm{CO}_{2}$-equiv./kWh for 2011, and the electricity cost for the domestic user is $0.23 \$ / \mathrm{kWh}$ [44]. When we 
TABLE 5: The emissions caused by PV-wind hybrid system and grid-fed system.

\begin{tabular}{lccccc}
\hline System & $\begin{array}{c}\text { Electricity prices } \\
\$ / \mathrm{kWH}\end{array}$ & $\begin{array}{c}\text { Emissions } \\
\mathrm{g} \mathrm{CO}_{2} \text {-equiv./kWh }\end{array}$ & $\begin{array}{c}\text { Daily load } \\
\mathrm{kWh} / \text { day }\end{array}$ & $\begin{array}{c}\text { Total load } \\
\mathrm{kWh} / \text { year }\end{array}$ & $\begin{array}{c}\text { Total emissions } \\
\mathrm{g} \mathrm{CO}_{2} \text {-equiv./kWh }\end{array}$ \\
\hline PV-wind hybrid & 0.89 & 82 & 3.0275 & 1142 & 92502 \\
Turkey grid & 0.23 & 493 & 3.0275 & 1142 & 563006 \\
\hline
\end{tabular}

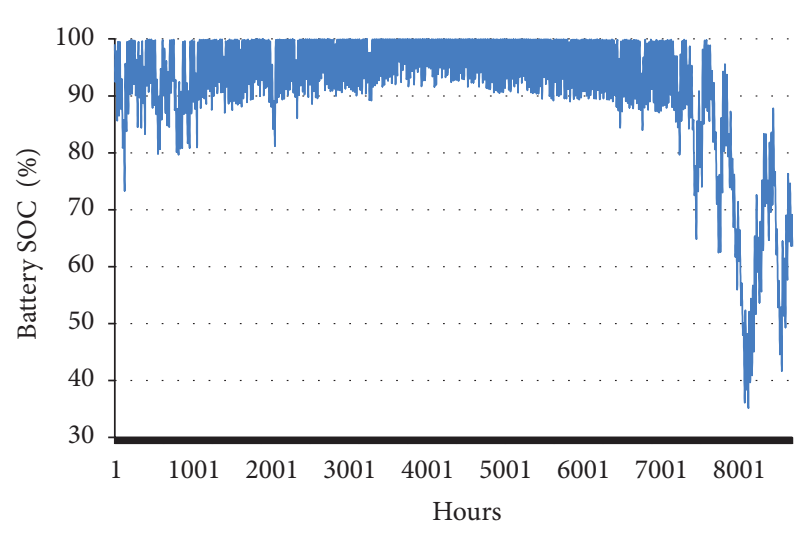

FIGURE 10: Measured results of SOC.

compare the grid-tied system with the hybrid system, gridtied consumers have greater emissions than autonomous PVwind hybrid systems, while their cost is lower. The PV-wind hybrid system observes an important decrease of emission to $563.006 \mathrm{~kg} /$ year; on the other hand, hybrid system energy cost is very high compared to grid electricity cost. The other hybrid systems have the same environmental conditions as 1.7 $\mathrm{kWh} / \mathrm{m}^{2}$-day; Panapakidis et al. calculated $0.975 \$ / \mathrm{kWh}$ with 69\% renewable fraction [45] and Dufo-López et al. calculated $0.647 \$ / \mathrm{kWh}$ with $211 \mathrm{~g} \mathrm{CO}_{2}$-equiv./kWh [46], whereas the studied system produces energy with a cost of $0.89 \$ / \mathrm{kWh}$ and an emission of $82 \mathrm{~g} \mathrm{CO}_{2}$-equiv./kWh.

\section{Conclusion}

A sizing procedure of a hybrid PV-wind energy system was presented. The outlined technique defines optimum hybrid energy system configuration and control criteria. It needs hourly changing meteorological data as input and contributes cost-effective hybrid system configuration with highest reliability. The procedure was applied for the sizing of PV-wind hybrid energy system that is considered to lighting of the Solar Energy Institute Building. Configured hybrid system was installed in January 2009 and the system variations were measured every 1 minute during one year. From the measured values, life cycle costs per $\mathrm{kWh}$ were calculated as $\$ 0.89$, LLP $=0.0428$, and also hourly changes of SOC are shown in Figure 10. The validation of the procedure was performed through the comparison between simulation results and derived results obtained from measurements.

\section{Nomenclature}

$C_{p}:$ Power coefficient

$C_{C}$ : Capital cost of hybrid system
$\mathrm{C}_{\mathrm{OP}}: \quad$ Operation cost

$\mathrm{CS}_{\mathrm{CPV}}$ : PV battery charger control switch

$\mathrm{CS}_{\mathrm{CWT}}$ : WT battery charger control switch

$\mathrm{CS}_{\text {IN }}:$ Inverter control switch

$\mathrm{CS}_{L}$ : Load control switch

$f_{\mathrm{MM}}$ : Mismatch factor for different types of modules

$G_{a, 0}: \quad$ Reference irradiation

$G_{a}: \quad$ Ambient irradiation

$I_{\mathrm{SC}, 0}^{C}: \quad$ Reference short-circuit current

$I_{\mathrm{SC}, 0}^{\mathrm{C}, 0}: \quad$ Short-circuit current of cell

$I_{\mathrm{SC}, 0}^{M}: \quad$ Short-circuit current of module

$I^{M}: \quad$ Module current

$I^{\mathrm{PV}}: \quad \mathrm{PV}$ array current

$I_{W}$ : Wind turbine current

$I_{\mathrm{BD}}: \quad$ Battery discharge current

$I_{\text {Load }}: \quad$ Load current

$I_{\mathrm{BC}}: \quad$ Battery charge current

$R_{S}^{M}: \quad$ Equivalent serial resistance of module

$R_{S}^{C}: \quad$ Equivalent serial resistance of cell

$\eta_{\mathrm{BC}}: \quad$ Efficiency for the battery charger

$\eta_{\text {inv }}: \quad$ Inverter efficiency

$N_{\text {SBat }}: \quad$ Number of series connected batteries

$N_{\mathrm{SC}}: \quad$ Number of series connected cells

$N_{\mathrm{PC}}$ : Number of parallel connected cells

$N_{\mathrm{SM}}: \quad$ Number of series connected modules

$N_{\mathrm{PM}}$ : Number of parallel connected modules

$N_{\text {PBAT }}$ : Number of parallel connected batteries

$P_{\mathrm{BC}-\mathrm{op}}$ : The output power of the battery charger

$\sigma_{i}: \quad$ Self-discharge losses of the battery

SOC: Battery stage of charge

$\mathrm{SOC}_{\text {min }}$ : Minimum SOC

$\mathrm{SOC}_{\max }$ : Maximum SOC

$V_{\mathrm{Ba}}: \quad$ Voltage of a battery

$V_{t}^{c}: \quad$ Thermal voltage, $\mathrm{mkT}^{\mathrm{C}} / \mathrm{e}$

$v: \quad$ Wind speed $(\mathrm{m} / \mathrm{s})$

$\rho_{\text {air }}: \quad$ Air density.

\section{References}

[1] Solarbuzz. Retail Price Summary, 2012, http://www.solarbuzz .com/facts-and-figures/retail-price-environment/module-prices.

[2] GWEC. Global Wind Energy Outlook, 2012, http://www.gwec .net/wp-content/uploads/2012/11/GWEO_2012_lowRes.pdf.

[3] T. Cronin, H. Bindner, P. Lundsager, and O. Gehrke, "Hybrid system performance evaluation," in Proceedings of the 27 th European Wind Energy Conference, Athens, Grece, 2006.

[4] A. Batman, F. G. Bagriyanik, Z. E. Aygen, Ö. Gül, and M. Bagriyanik, "A feasibility study of grid-connected photovoltaic 
systems in Istanbul, Turkey," Renewable and Sustainable Energy Reviews, vol. 16, no. 8, pp. 5678-5686, 2012.

[5] G. Bekele and B. Palm, "Feasibility study for a standalone solarwind-based hybrid energy system for application in Ethiopia," Applied Energy, vol. 87, no. 2, pp. 487-495, 2010.

[6] G. J. Dalton, D. A. Lockington, and T. E. Baldock, "Feasibility analysis of stand-alone renewable energy supply options for a large hotel," Renewable Energy, vol. 33, no. 7, pp. 1475-1490, 2008.

[7] M. J. Khan and M. T. Iqbal, "Pre-feasibility study of standalone hybrid energy systems for applications in Newfoundland," Renewable Energy, vol. 30, no. 6, pp. 835-854, 2005.

[8] M. Lalwani, D. P. Kothari, and M. Singh, "Viability analysis by techno-economic aspects of grid interactive solar photovoltaic project in indiaon," in Proceedings of the International Conference on Advances in Engineering, Science and Management (ICAESM '12), 2012.

[9] R. Luna-Rubio, M. Trejo-Perea, D. Vargas-Vázquez, and G. J. Ríos-Moreno, "Optimal sizing of renewable hybrids energy systems: a review of methodologies," Solar Energy, vol. 86, no. 4, pp. 1077-1088, 2012.

[10] S. M. Shaahid and M. A. Elhadidy, "Technical and economic assessment of grid-independent hybrid photovoltaic-dieselbattery power systems for commercial loads in desert environments," Renewable and Sustainable Energy Reviews, vol. 11, no. 8, pp. 1794-1810, 2007.

[11] E. I. Zoulias and N. Lymberopoulos, “Techno-economic analysis of the integration of hydrogen energy technologies in renewable energy-based stand-alone power systems," Renewable Energy, vol. 32, no. 4, pp. 680-696, 2007.

[12] J. L. Bernal-Agustín and R. Dufo-López, "Simulation and optimization of stand-alone hybrid renewable energy systems," Renewable and Sustainable Energy Reviews, vol. 13, no. 8, pp. 2111-2118, 2009.

[13] A. N. Celik, "Optimisation and techno-economic analysis of autonomous photovoltaic-wind hybrid energy systems in comparison to single photovoltaic and wind systems," Energy Conversion and Management, vol. 43, no. 18, pp. 2453-2468, 2002.

[14] M. K. Deshmukh and S. S. Deshmukh, "Modeling of hybrid renewable energy systems," Renewable and Sustainable Energy Reviews, vol. 12, no. 1, pp. 235-249, 2008.

[15] S. Diaf, G. Notton, M. Belhamel, M. Haddadi, and A. Louche, "Design and techno-economical optimization for hybrid PV/ wind system under various meteorological conditions," Applied Energy, vol. 85, no. 10, pp. 968-987, 2008.

[16] F. Giraud and Z. M. Salameh, "Steady-state performance of a grid-connected rooftop hybrid wind-photovoltaic power system with battery storage," IEEE Transactions on Energy Conversion, vol. 16, no. 1, pp. 1-7, 2001.

[17] A. Gupta, R. P. Saini, and M. P. Sharma, "Steady-state modelling of hybrid energy system for off grid electrification of cluster of villages," Renewable Energy, vol. 35, no. 2, pp. 520-535, 2010.

[18] E. Koutroulis, D. Kolokotsa, A. Potirakis, and K. Kalaitzakis, "Methodology for optimal sizing of stand-alone photovoltaic/ wind-generator systems using genetic algorithms," Solar Energy, vol. 80, no. 9, pp. 1072-1088, 2006.

[19] M. P. McHenry, "Are small-scale grid-connected photovoltaic systems a cost-effective policy for lowering electricity bills and reducing carbon emissions A technical, economic, and carbon emission analysis," Energy Policy, vol. 45, pp. 64-72, 2012.
[20] A. N. Celik, "Techno-economic analysis of autonomous PVwind hybrid energy systems using different sizing methods," Energy Conversion and Management, vol. 44, no. 12, pp. 19511968, 2003.

[21] K. H. Park, C. U. Kang, G. M. Lee, and J. H. Lim, "Design of optimal combination for new and renewable hybrid generation system," Communications in Computer and Information Science, vol. 266, pp. 189-198, 2011.

[22] S. Sayeef, N. Mendis, and K. Muttaqi, "Optimisation of component sizes for a hybrid remote area power supply system," in Proceedings of the 19th Australasian Universities Power Engineering Conference: Sustainable Energy Technologies and Systems (AUPEC '09), IEEE, September 2009.

[23] H. Yang, Z. Wei, and L. Chengzhi, "Optimal design and technoeconomic analysis of a hybrid solar-wind power generation system," Applied Energy, vol. 86, no. 2, pp. 163-169, 2009.

[24] G. M. Tina and S. Gagliano, "Probabilistic modelling of hybrid solar/wind power system with solar tracking system," Renewable Energy, vol. 36, no. 6, pp. 1719-1727, 2011.

[25] K. Ulgen and A. Hepbasli, "A study on evaluating the power generation of solar-wind hybrid systems in Izmir, Turkey," Energy Sources, vol. 25, no. 3, pp. 241-252, 2003.

[26] Siemens. SM 10 solar module, 2012, http://www.siemen.co.uk/ sm10.html.

[27] Exide. Sonnenschein Batterien, 12V, 10AH, 2012, http://www .farnell.com/datasheets/332192.pdf.

[28] A. McEvoy, T. Markvart, and L. Castañer, Practical Handbook of Photovoltaics: Fundamentals and Applications, Academic Press, Amsterdam, The Netherlands, 2012.

[29] C. Luis and S. Silvester, Modeling Photovoltaic Systems Using Pspice, John Wiley \& Sons, 2002.

[30] A. D. Hansen, P. Sorensen, L. H. Hansen, and H. Binder, "Models for a stand-alone PV system," Tech. Rep., Risø National Laboratory, Roskilde, Denmark, 2001.

[31] N. A. Orlando, M. Liserre, V. G. Monopoli, R. A. Mastromauro, and A. Del'Aquila, "Comparison of power converter topologies for permanent magnet small wind turbine system," in Proceedings of the IEEE International Symposium on Industrial Electronics (ISIE '08), pp. 2359-2364, July 2008.

[32] A. B. Cultura and Z. M. Salameh, "Modeling and simulation of a wind turbine-generator system," in Power and Energy Society General Meeting, IEEE, 2011.

[33] O. Tremblay, L. A. Dessaint, and A. I. Dekkiche, "A generic battery model for the dynamic simulation of hybrid electric vehicles," in Vehicle Power and Propulsion Conference (VPPC '07), pp. 284-289, IEEE, September 2007.

[34] M. Engin, Güneş-Rüzgâr Hibrid Enerji ile su Pompalama.

[35] G. C. Seeling-Hochmuth, Optimization of Hybrid Energy Systems Sizing and Operation Control, University of Kassel, 1998.

[36] T. Senjyu, D. Hayashi, N. Urasaki, and T. Funabashi, "Optimum configuration for renewable generating systems in residence using genetic algorithm," IEEE Transactions on Energy Conversion, vol. 21, no. 2, pp. 459-466, 2006.

[37] MATLAB. MATLAB/SIMULINK, 2012, R2012b:[MATLAB is a high-level language and interactive environment for numerical computation, visualization, and programming], http://www .mathworks.com/.

[38] I. E. Commission, International Standard IEC 61724: Photovoltaic System Performance Monitoring-Guidelines for Measurements, Data Exchange and Analysis, IEC, 1998. 
[39] L. Arribas, L. Cano, I. Cruz, M. Mata, and E. Llobet, "PV-wind hybrid system performance: a new approach and a case study," Renewable Energy, vol. 35, no. 1, pp. 128-137, 2010.

[40] V. M. Fthenakis and H. C. Kim, "Photovoltaics: life-cycle analyses," Solar Energy, vol. 85, no. 8, pp. 1609-1628, 2011.

[41] J. Peng, L. Lu, and H. Yang, "Review on life cycle assessment of energy payback and greenhouse gas emission of solar photovoltaic systems," Renewable and Sustainable Energy Reviews, vol. 19, no. 0, pp. 255-274, 2013.

[42] A. Stoppato, "Life cycle assessment of photovoltaic electricity generation," Energy, vol. 33, no. 2, pp. 224-232, 2008.

[43] H. L. Raadal, L. Gagnon, I. S. Modahl, and O. J. Hanssen, "Life cycle greenhouse gas (GHG) emissions from the generation of wind and hydro power," Renewable and Sustainable Energy Reviews, vol. 15, no. 7, pp. 3417-3422, 2011.

[44] EPDK. Elektrik Piyasası Raporu 2011, 2012, http://www.epdk .org.tr/index.php/elektrik-piyasasi/yayinlar-raporlar.

[45] I. P. Panapakidis, D. N. Sarafianos, and M. C. Alexiadis, "Comparative analysis of different grid-independent hybrid power generation systems for a residential load," Renewable and Sustainable Energy Reviews, vol. 16, no. 1, pp. 551-563, 2012.

[46] R. Dufo-López, J. L. Bernal-Agustín, J. M. Yusta-Loyo et al., "Multi-objective optimization minimizing cost and life cycle emissions of stand-alone PV-wind-diesel systems with batteries storage," Applied Energy, vol. 88, no. 11, pp. 4033-4041, 2011. 

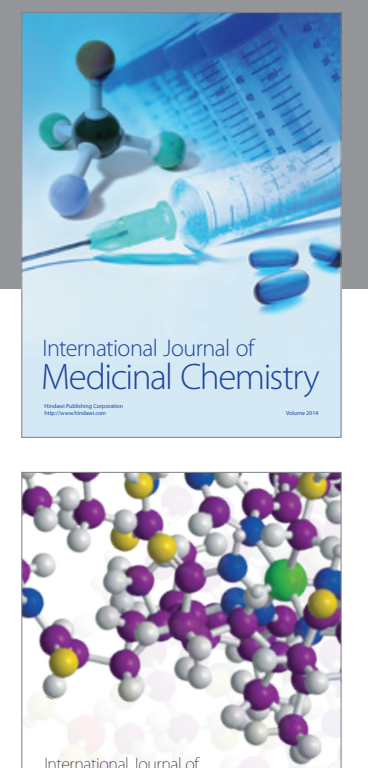

\section{Carbohydrate} Chemistry

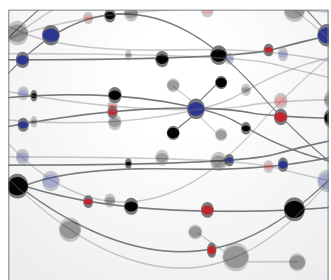

The Scientific World Journal
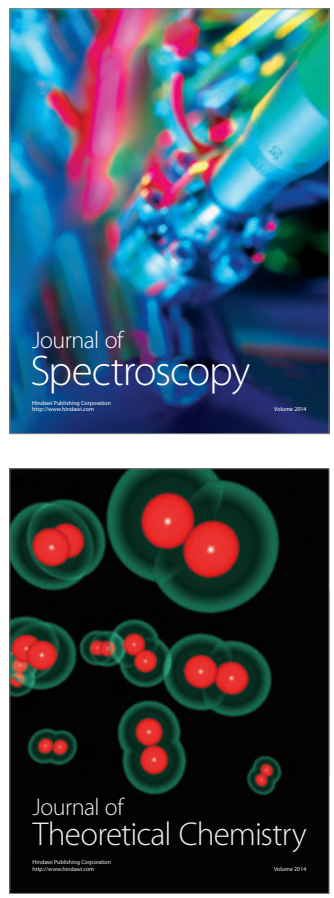
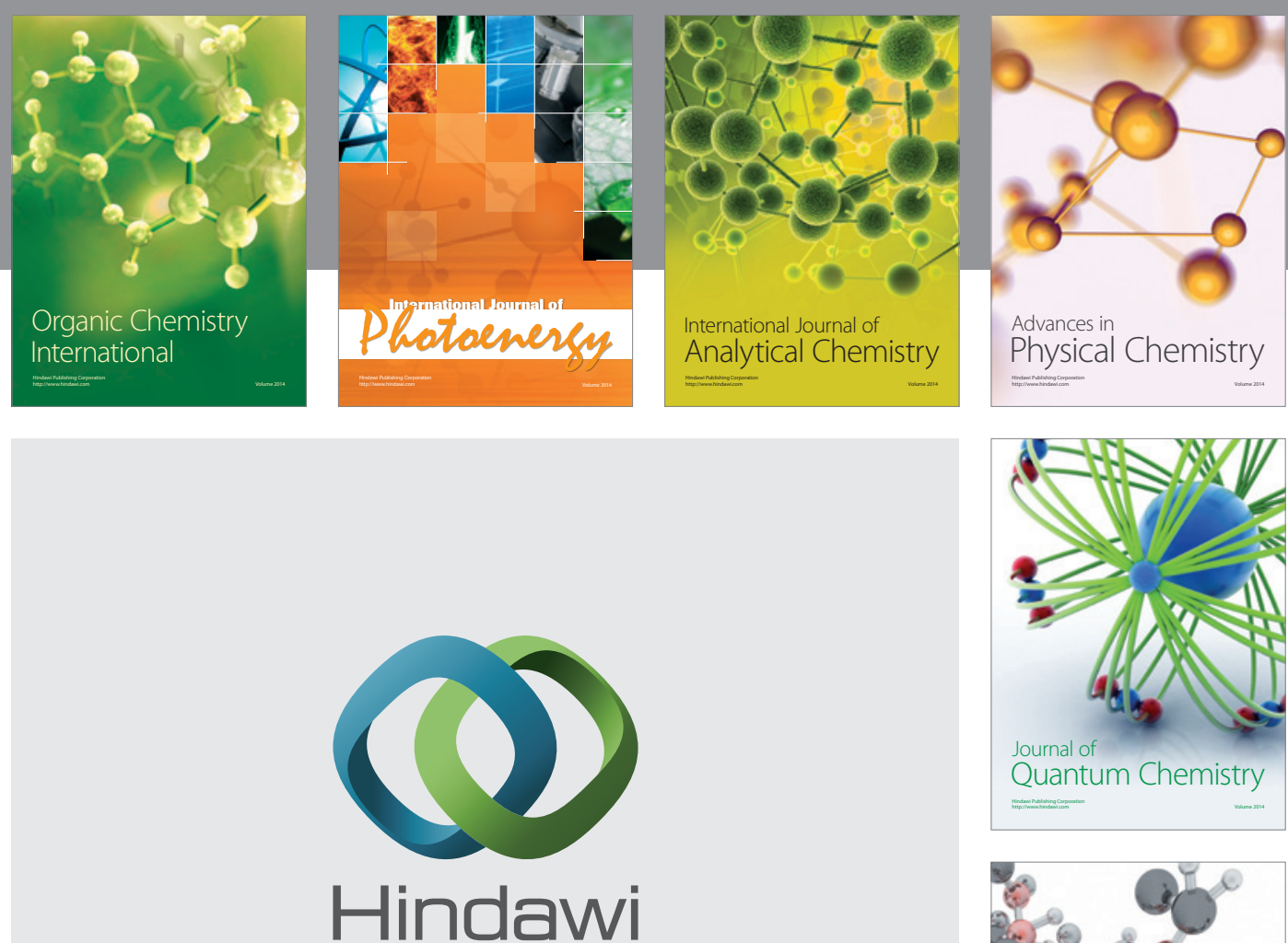

Submit your manuscripts at

http://www.hindawi.com

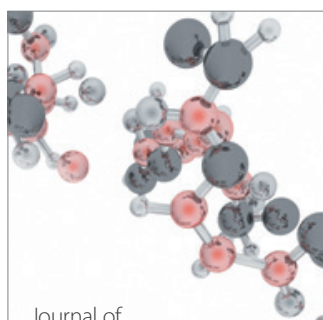

Analytical Methods

in Chemistry

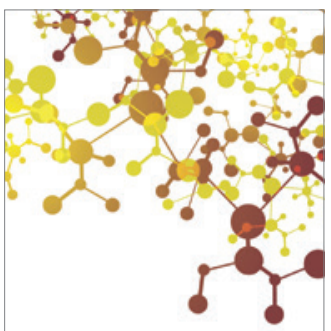

Journal of

Applied Chemistry

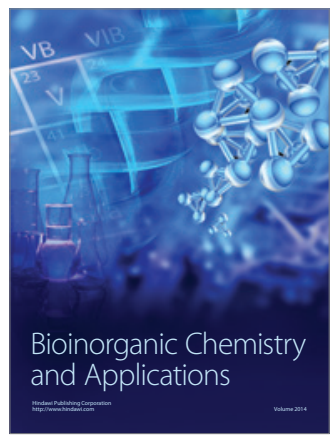

Inorganic Chemistry
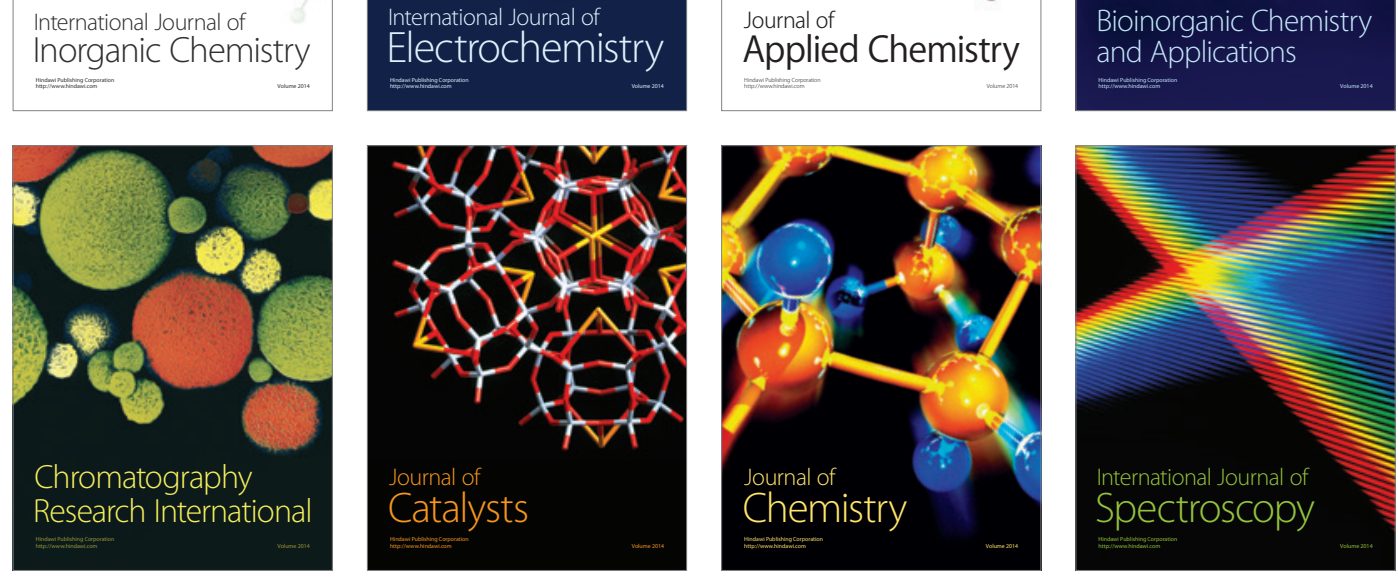